\title{
“Le Temps Suspendu”: Suspended Time, Surrealism and Shamanic Myth
}

\author{
Kurt Cline \\ National Taipei University of Technology, Taiwan, China \\ Email: kcline@ntut.edu.tw
}

Received 15 March 2016; accepted 22 April 2016; published 25 April 2016

Copyright (C) 2016 by author and Scientific Research Publishing Inc.

This work is licensed under the Creative Commons Attribution International License (CC BY). http://creativecommons.org/licenses/by/4.0/

(c) (i) Open Access

\begin{abstract}
A close examination of Rene Clair's films Paris qui Dort and Entr'acte reveals a connection between Clair's cinematic technique of "instantanéisme" and Breton's notion of "suspended time". The Surrealist Voice emerges from the liminal state between sleeping and waking as "spoken thought", the voice of being revealing itself to the poet. It is poesis speaking itself.
\end{abstract}

\section{Keywords}

\section{Surrealism, Film, Poetics}

Breton and the Parisian Surrealists demonstrate a keen awareness of shamanic motifs and praxis. In René Clair's 1922 film Paris qui Dort [When Paris Sleeps], the Eiffel Tower might stand in for the shamanic tree. At the film's beginning, the protagonist, Albert (Henri Rollin) is evidently a doorkeeper on a platform of the famous Parisian landmark. He awakens in the morning and descends down a long spiral staircase to the world below. It was Paris asleep, as it was at 3:25 that morning. Only now it is after dawn and our protagonist finds himself in a ghost-town. People everywhere are frozen, suspended in time while partying at a fashionable nightclub or on the brink of suicide or just about to be caught by the police, asleep in cars or on benches. They are alive but unconscious. Only our protagonist and the passengers of a recently landed airplane remain sentient. The six take up residence in the Eiffel Tower. With all of Paris quite inert, they have everything they've ever desired, but still they are lonely. There's only one woman for five men. A message comes them on the wireless from the daughter of the mad scientist who invented the ray that put the city asleep. Henri Rollin and his associates soon free the girl and compel her father to change things back-with mixed results, however. Our modern day Crusoes enjoyed their liminal state. Now they must resume their normal existences. Before too long, all six have been locked up in the psychiatric hospital. They can only gain their freedom by taking on consensus reality, and admitting that they have been deluded. 
The shamanic otherworld is Paris asleep. It is a liminal region that can only be reached by shamanic flight (represented by the airplane and its passengers) or shamanic descent. Only the shamans, the travelers between worlds, can step outside of time and see the real reality, the eternality behind apparent movement. The Eiffel Tower is the shamanic tree, its girders, catwalks and stairways affording our travelers and camera a great verticality of movement by which they can pass from world to world, from wake to sleep, from utopia to dystopia. The Surrealist shamanic descent is into the heart of the sickness of modern civilization - the death of its living connection with the shamanic otherworld. Propelled by a "wireless voice", the six adventurers free Persephone from the Underworld. But they are unable, finally, to change the real world, and must become part of it or be locked away. Indeed, they made matters worse, since now time has inadvertently been speeded up. Still our protagonist has had a happier result than poor Orpheus. He and the mad scientist's daughter are able to return to the Eiffel Tower and see it with new understanding as a communicating vessel between interpenetrating realities. This understanding is the love they share.

In both this film and 1924's Entr'acte, which features a Kandinsky-esque shamanic flying boat soaring above Paris, Clair (1924) figures time as illusory and malleable. Entr'acte does this by bending time itself, speeding up, slowing down, or stopping it altogether, in a series of comic scenes. In Paris qui Dort time is running away with everyone's lives. The suicide on the bank of the Seine carries with the stones in his pockets a note saying that he can no longer take the fast paced life. The six shamanic voyagers are able to escape from time-if temporarily_-by seeing that it is an illusion. The two lovers are able to recreate the knowledge_gnosis—of that illusion in one another. The theme of time is intertwined with shamanic motifs in many Surrealist works. In Salvador Dali's The Persistence of Memory (1931) time literally hangs suspended, like a dishrag over the barren branches of a tree. Gigantic pocket watches, are bent, dripping, or crawling with ants. Time and memory are distorted, arising out of decay, and receding into a dead flat ocean of pure possibility. Dali's dream-world is a shamanic otherworld in the visual presentation of which are intermingled tensions between life and death, activity and stillness, and timelessness and time.

What Breton calls "le temps suspend” [suspended time] (Breton, 1982: p. 118) necessary for the creation of art, can be achieved through a number of Surrealist techniques. The foremost poetic principle articulated by Breton is automatism. The idea for "spontaneously irrupting autonomous phrases" came to Breton one evening, as he relates in his 1924 Manifesto of Surrealism, just as he was about to fall asleep. It was in this liminoid state between sleeping and waking that Breton perceived, "so clearly articulated that it was impossible to change a word, but nonetheless removed from the sound of any voice a rather strange phrase which came to me without any apparent relationship" (Breton, 1972: p. 21) to the events of the day. The phrase seems to him insistent, as if it were "knocking at the window" (Breton, 1972: p. 21). "It was something like: "There is a man cut in two by a window"”, Breton notes, "accompanied by the faint visual image of a man walking cut by a window perpendicular to the axis of his body" (Breton, 1972: pp. 21-22). Breton realizes that he is "dealing with an image of a rather rare sort”, and immediately he starts thinking of how he might incorporate this paradoxical phrasewhich unfortunately he cannot remember-into his poetry. The first phrase is then succeeded by a whole series of phrases quite beyond Breton's conscious control.

Making possible the creation of the Surrealist image is what Breton calls "the Surrealist voice” (Breton, 1972: p. 45). That is, the poetic image as "spoken thought” (Breton, 1972: p. 23), is in the first place spoken. It is articulated inside the mind, and is "heard” by the poet. In Paris qui Dort, Clair articulates this idea as "the wireless voice”, a message from, metaphorically, the subconscious, since the mad scientist's daughter, imprisoned in Hell, can be identified with Eurydice or Persephone, the repressed feminine intuitive voice. Cocteau's Orpheus also receives messages from the underworld over the radio of his car. This also implies an interior orality since the car or vehicle can stand for Orpheu's consciousness itself. As in Breton's figuration, the poet is inside his own mind listening to messages. But where do these messages come from? Are they broadcast in from some exterior source? Who or what is the voice speaking the phrase, and who or what is doing the listening, the remembering? Shamans usually describe the special information they receive as coming from outside of themselves. However, this may only be metaphorical. In dreams we seem to see a world outside of ourselves, yet we locate this world within what we call the dreaming mind, a purely hypothetical construct. The Surrealist Voice is conceived as coming from within, but how does this voice within articulate things of which the conscious mind is unaware?

Because of the prevalence of this interior voice, Breton's poetics actually goes back to the oral compositional base of the shaman's song. The poem is spoken before it is written. For Isaac Tens, the chant precedes its manifestation. First the song comes, and then the images which the song summons forth. Similarly, the surrealist 
phrase as inwardly articulated precedes its visual image which trails after it and shifts position in space. A moment later the man is horizontal, leaning out the window. Breton's image—an "apparition", he calls it—occurs to him as it did to the Gitksan shaman—-spontaneously, without the conscious will of the singer. Moreover, the image which appears through the singing is, as Humphries has remarked about the images employed in songs of the Daur Mongol shamans, "counter-intuitive” and "unnatural” (Humphries \& Urgunge, 1996: p. 59). Likewise the Surrealist image—both "arbitrary" and "hallucinatory" (Breton, 1972: p. 38), in which were juxtaposed two more of less distant "realities" (Breton, 1972: p. 20)—embodies paradox and contradiction, and supports a finely held tension between an entire network of oppositions. Breton offers as an example of the Surrealist image Lautréamont's "The ruby of champagne" (Breton, 1972: p. 38).

Like the shaman, the surrealists explored non-normative states of consciousness-including dreaming, trance, madness, hypnosis, meditation, telepathy, automatism and intoxication from opium, hashish, and absinthe-in order to obtain special knowledge, that is, information from beyond the spatio-temporal boundaries of the inquirer's senses. Although they employ the Freudian paradigm in postulating the origin of the Surrealist Voice as the subconscious or unconscious, there is a strong connection between mental and physical spheres, which, under the guise of chance, connect with, comment upon and blend into one another in an uncanny fashion. Breton defines the chance occurrence as "the encounter of an external causality with an internal finality" (Breton, 1987: p. 21). The Surrealist image operates at this nexus, between flux and eternality. Its source of its power-its proof, if you will-lies in the synchronicity which it is both record of and participant in.

In Surrealism and the Sacred, Professor Rabinovitch ably demonstrated that the purpose of the Surrealist explorations was, at root, religious. In the weird, the uncanny, the epiphany and even the repellent is the full contradiction and meaning that encompasses oppositions that is characteristic of the sacrality of religious experience. While Rabinovitch describes Surrealism as a "special state of mind" (Rabinovitch, 2002: p. 40), I might call it a state specific practice in which the marvelous is ferreted out through recourse to classical shamanic methods that have been transformed by the exigencies of the modern world. Automatism-the uncovering of synchronicities-might be thought of as a mantic activity. Through oneiromany, cleromancy and sortilege as well as otherworldly sojourns information is obtained from a fantastic world located both inside and yet somehow apart from the consciousness of the observer. The Surrealist Voice is the voice of being revealing itself to the poet. It is poesis itself, speaking.

\section{References}

Breton, A. (1972). Manifestoes of Surrealism. R. Seaver, \& H. R. Lane (Trans.). Ann Arbor: University of Michigan Press.

Breton, A. (1982). Poems. J.-P. Cauvin, \& M. A. Caws (Trans.). Austin: University of Texas Press.

Breton, A. (1987). Mad Love. M. A. Caws (Trans.). Lincoln: University of Nebraska Press.

Clair, R. (1922). Paris qui Dort.

Clair, R. (1924). Entr'acte.

Humphries, C., \& Urgunge, O. (1996). Shamans and Elders: Experience, Knowledge and Power among the Daur Mongols. Oxford: Clarendon Press.

Rabinovitch, C. (2002). Surrealism and the Sacred. Ann Arbor: University of Michigan Press. 